\title{
Marble mylonites in the Bancroft shear zone, Ontario, Canada: microstructures and deformation mechanisms
}

\author{
Ben A. van der Pluijm \\ Department of Geological Sciences, University of Michigan, Ann Arbor, MI 48109, U.S.A.
}

(Received 17 September 1990; accepted in revised form 2 May 1991)

\begin{abstract}
Mylonitization of medium-grade marbles in the Bancroft shear zone, Ontario, Canada, is characterized by decreasing grain-size of both calcite and graphite, and a variety of textures. Calcite grain-sizes vary from several millimeters in the protolith, to $50-200 \mu \mathrm{m}$ in mylonite, to $<30 \mu \mathrm{m}$ in ultramylonite. Corresponding calcite grain shapes are equant in the protolith, elongate in protomylonite (first-developed dimensional preferred orientation), equant in coarse mylonite, elongate in fine mylonite (second-developed dimensional preferred orientation) and generally equant in ultramylonite, which suggests that external energy (applied stress) that tends to elongate grains competed with internal energy sources (e.g. distortional strain) that favor equant shapes. Graphite grain-size changes from several millimeters to centimeters in the protolith to submicroscopic in ultramylonite. In the mylonitic stages, graphite is present as dark bands, while in the ultramylonitic stage it is preserved as a fine coating on calcite grains.

Based on textural evidence, twinning (exponential creep; regime I), dynamic recrystallization (power law creep; regime II) and possibly grain boundary sliding superplasticity (regime III) are considered the dominant deformation mechanisms with increasing intensity of mylonitization; their activity is largely controlled by calcite grain-size. Calcite grain-size reduction occurred predominantly by the process of rotation recrystallization during the early stages of mylonitization, as indicated by the occurrence of core and mantle or mortar structures, and by the grain-size of subgrains and recrystallized grains. Grain elongation in $S-C$ structures indicates the activity of migration recrystallization; these structures are not the result of flattening of originally equant grains. Differential stress estimates in coarse mylonites and ultramylonites, based on recrystallized grain-size, are 2-5 and 14-38 MPa, respectively. Initial grain-size reduction of graphite occurred by progressive separation along basal planes, analogous to mica fish formation in quartzo-feldspathic mylonites.

Calcite-graphite thermometry on mylonitic and ultramylonitic samples shows that the metamorphic conditions during mylonitization were $475 \pm 50^{\circ} \mathrm{C}$, which, combined with a differential stress value of $26 \mathrm{MPa}$, gives a strain rate of $1.2 \times 10^{-10} \mathrm{~s}^{-1}$ based on constitutive equations; corresponding displacement rates are $<38 \mathrm{~mm} \mathrm{yr}^{-1}$.
\end{abstract}

\section{INTRODUCTION}

Deformation experiments that have been carried out during the past several decades have produced a remarkably detailed record of the behavior of carbonates under laboratory conditions (e.g. Turner et al. 1954, Griggs et al. 1960, Heard \& Raleigh 1972, Rutter 1974, Rutter \& Schmid 1975, Rutter \& Rusbridge 1977, Schmid et al. 1977, 1980, 1987, Spiers 1979, Friedman \& Higgs 1981, Schmid 1982, Groshong et al. 1984, Wenk et al. 1986, 1987, Borradaile \& McArthur 1990, Rowe \& Rutter 1990 , de Bresser 1991). One of the principal aims of such experiments is to determine the characteristic deformation mechanism for conditions of differential stress $(\sigma)$, temperature $(T)$, strain rate $(\dot{e})$ and grain size $(d)$, and to extrapolate the results to geologic conditions. In contrast to this extensive experimental database, studies on microstructures in naturally deformed carbonates are much more limited (e.g. Barber \& Wenk 1979, Schmid et al. 1981, Schmid 1982, Dietrich \& Song 1984, Heitzmann 1987). This may in part be attributed to the emphasis that has been placed on shear zones that are related to thrusting. Thermal equilibration after relatively instantaneous thrusting (e.g. England \& Thompson 1984) facilitates static recrystallization (annealing) and the destruction of deformation microstructures. This holds particularly true for calcite. Griggs et al. (1960) found that annealing of carbonates occurs rapidly at temperatures over $500^{\circ} \mathrm{C}$. Consequently, only marble mylonites that were formed in regions that never exceeded middle to upper greenschist facies conditions, or those formed during the retrograde history of higher grade rocks, will have preserved their original deformation microstructures.

In this paper the microstructures of marble mylonites are described from an anastomising shear zone, the Bancroft shear zone (Carlson et al. 1990) in the Grenville Province of southern Ontario (Fig. 1), in which a complete sequence from protolith to ultramylonite is preserved. The microstructures of the various mylonitic textures and their dominant deformation mechanisms are analyzed in the light of studies of experimentally deformed carbonates. Furthermore, the temperature of mylonitization $\left(475 \pm 50^{\circ} \mathrm{C}\right)$ is determined using calcitegraphite geothermometry. Deformation mechanism maps at these uppermost greenschist facies conditions are calculated from experimentally-derived constitutive equations. These data collectively provide information on the differential stress magnitude, strain rate and displacement rate associated with this mylonite zone.

\section{GEOLOGIC SETTING}

The Grenville Province in southern Ontario (Fig. 1) is subdivided into three main tectonostratigraphic zones; from west to east they are: the Central Gneiss Belt (CGB), dominated by high-grade metaigneous rocks, 


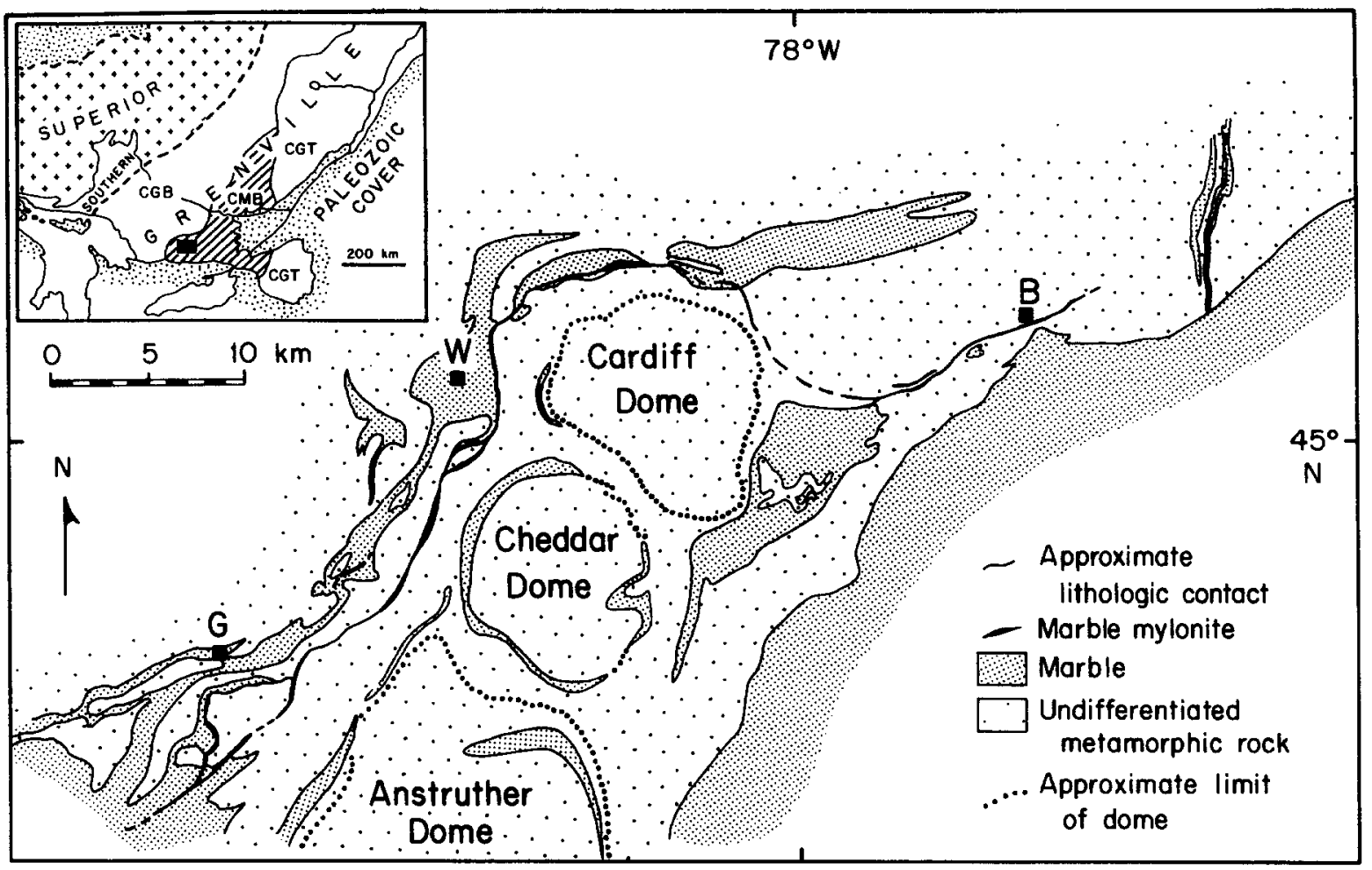

Fig. 1. Major subdivision of the Grenville of North America (inset), and simplified lithologic map of the area that contains the Bancroft shear zone. Abbreviations are: $B=$ Bancroft, $C G B=$ Central Gneiss Belt, CGT = Central Granulite Terrane, $\mathrm{CMB}=$ Central Metasedimentary Belt, $\mathrm{G}=$ Gooderham, $\mathrm{W}=$ Wilberforce. Map simplified from Carlson $\mathrm{et}$ al . (1990) and references therein.

the Central Metasedimentary Belt (CMB), dominated by medium- to high-grade metasedimentary and metaigneous rocks, and the Central Granulite Terrane (CGT), dominated by high-grade metaigneous rocks including anorthosites (Wynne-Edwards 1972, Davidson 1986). The Bancroft shear zone is located in the western portion of the CMB and separates middle to upper amphibolite-grade gneisses and marbles of the Bancroft domain from overlying greenschist to lower amphibolite-grade gneisses, metavolcanics and marbles of the Elzevir domain (Carlson et al. 1990) (Fig. 1). The Bancroft shear zone is a narrow, anastomosing belt of predominantly mylonitic marbles; locally, mylonitized granitic rocks are present. The thickness of individual shear zones is $<20 \mathrm{~m}$, with an overall width of the anastomosing zone $<2 \mathrm{~km}$ (Fig. 1). Well-preserved shear-sense indicators in this shallowly SE-dipping zone indicate top side (i.e. Elzevir domain) down. Widespread thrusting (Davidson 1986, Mawer 1987, Hanmer 1988) predates and coincides with extension, and van der Pluijm \& Carlson (1989) speculated that extension in this area reflects the gravitational collapse of an overthickened orogenic wedge.

\section{MICROSTRUCTURES}

Four microstructural types are recognized in the marbles of this study: protolith, protomylonite, mylonite (coarse and fine) and ultramylonite. These types represent an increase in intensity of mylonitization from relatively undeformed (protolith) to most highly deformed (ultramylonite). The boundary between these types is arbitrary, because a gradation between each exists. However, each type is readily recognized by field characteristics such as color and grain size (Carlson et al. 1990), and by the microstructural characteristics described below.

All thin sections were cut perpendicular to the foliation plane and parallel to the lineation, i.e. parallel to $X Z$. In samples without foliations and/or lineations the regional orientation was used. The microstructures that are illustrated in Fig. 2, and the reported grain-size measurements, were obtained from five representative sections. Microstructures were digitized from photomosaics using a digitizing tablet. JANDEL software was used to calculate the mean grain size and standard deviation of at least 300 grains per section; the long dimension is reported for elongate grains.

\section{Protolith}

Samples of the protolith are characterized by coarse, relatively strain-free grains in thin section. The grainsize of a representative sample (GO-2D) ranges from 2 to $6 \mathrm{~mm}$ (mean $3.2 \pm 1.1 \mathrm{~mm}$ ). Most calcite grains are equant and show slightly serrated grain boundaries that meet in triple points. In almost all grains, calcite twins are present (Fig. 2a). Graphite is recognizable in hand specimen as well as in thin section, and occurs as large, euhedral flakes (1-20 mm, measured in the basal planes) that are randomly oriented in the marble matrix. 


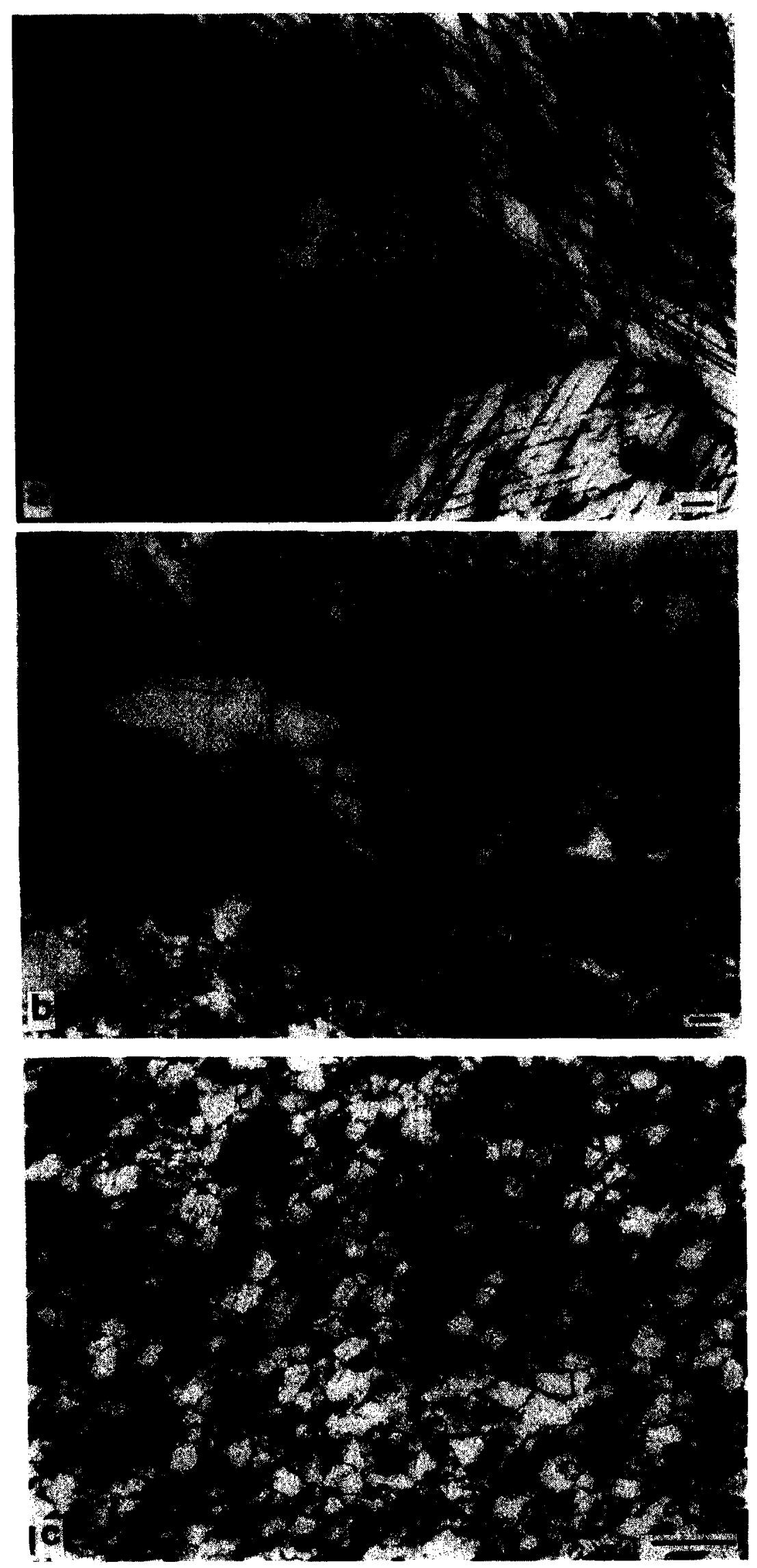

Fig. 2. Photomicrographs of marble microstructures in the Bancroft shear zone. (a) Protolith. (b) Protomylonite (c) Coarse mylonite. Scale bars $200 \mu \mathrm{m}$. 

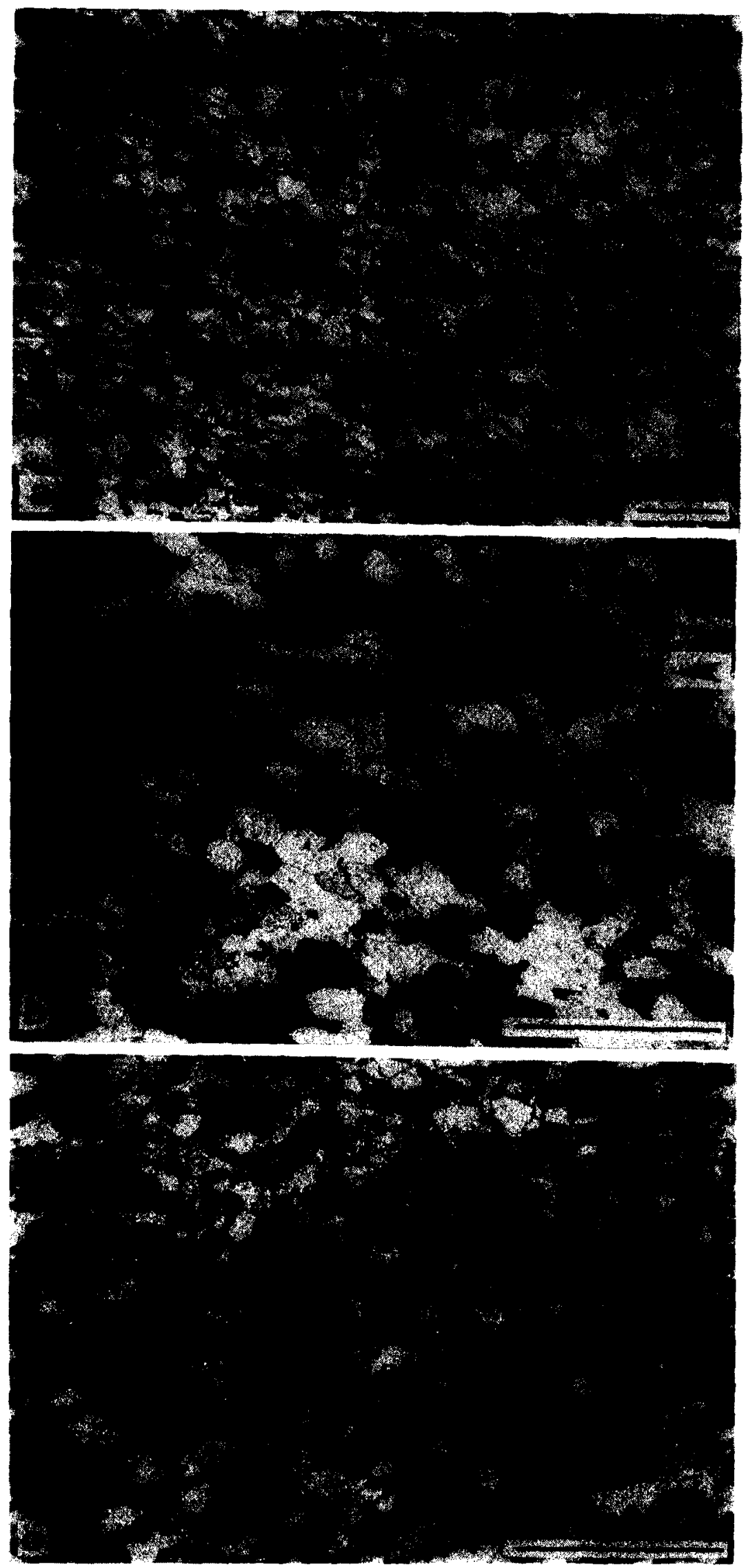

Fig. 3. Photomicrographs of marble microstructures in the Bancroft shear zone. (a) \& (b) Fine mylonite. (c) Ultramylo nite. Scale bars $200 \mu \mathrm{m}$. 


\section{Protomylonite}

Slightly elongate, large calcite grains (mean $2.3 \pm 1.0 \mathrm{~mm}$; sample GO-4B) and a population of smaller grains $(50-150 \mu \mathrm{m})$ characterize the protomylonitic marbles in thin section (Fig. $2 \mathrm{~b}$ ). The elongate large grains define a weak dimensional preferred orientation (DPO) that is parallel to the foliation ( $C$-surface) in more strongly mylonitized samples. Deformation bands, undulose extinction and bent twins are present in the large grains, and subgrains and recrystallized grains commonly decorate their edges. The term 'subgrain' is used when the crystallographic mismatch across a grain boundary is $<10^{\circ}$, following the convention of White (1976) and Poirier (1985). The microstructure has the appearance of a core and mantle or mortar structure, which is common in deformed quartzose rocks (White 1976). Graphite flakes have ragged edges and are oriented roughly parallel to elongate calcite grains. Their DPO is responsible for a weak lineation in outcrop.

\section{Mylonite}

Mylonite samples were subdivided into coarse and fine mylonites. In a representative sample of coarse mylonite (WI-1D), there is a single population of generally equant grains with a mean grain size of $153 \pm 67 \mu \mathrm{m}$ (Fig. 2c). Occasionally, a slight grain elongation is observed, but this feature is much more pronounced in the fine mylonite (see below). Straight grain boundaries that meet in triple points (foam texture) characterize the calcite microstructure of coarse mylonites. Darks bands consisting mainly of fine-grained graphite define a welldeveloped foliation; some individual graphite flakes can still be recognized, but in most of these bands finegrained, amorphous graphite dominates.

Fine mylonites typically show pronounced calcite grain elongation. The long dimension of elongate grains is $47 \pm 22 \mu \mathrm{m}$ and is oriented at an angle of about $35^{\circ}$ to the graphitic foliation (sample GO-6; Fig. 3a). This geometry is identical to $S-C$ structures in quartzofeldspathic mylonites (e.g. Berthé et al. 1979, Lister \& Snoke 1984) and its significance for the sense of shear is in agreement with extension (Carlson et al. 1990). The long dimension of elongate grains in $S-C$ structures is less than the mean grain-size of grains in the coarse mylonite. The grain-size of calcite in $C$-surfaces is further reduced and grains are elongate parallel to this foliation (Fig. 3b). As in the coarse mylonite, individual graphite grains are no longer recognizable.

\section{Ultramylonite}

Ultramylonites are easily recognizable in outcrop by their dark gray to black color and their extremely fine grain-size. Sometimes an irregular foliation anastomoses around clasts of other lithologies such as granite and amphibolite that were incorporated into the shear zone. In thin section, the foliation is defined by slight grain elongation of calcite, however, equant calcite

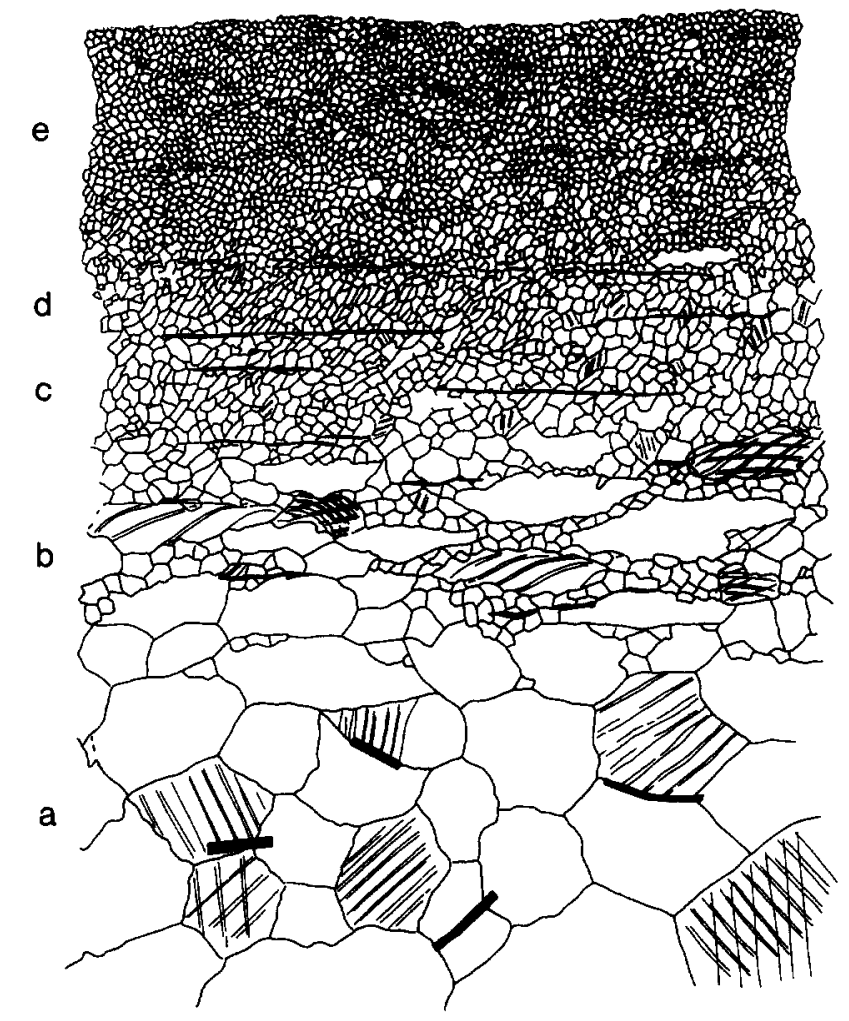

Fig. 4. Composite sketch of microstructures in the Bancroft shear zone, showing relative positions of (a) protolith, (b) protomylonite, (c) coarse mylonite, (d) fine mylonite and (e) uitramylonite.

grains are equally common. Figure 3(c) shows a representative example (BA-3D) of this mylonite type; the calcite grain size is $22 \pm 10 \mu \mathrm{m}$. Finely disseminated graphite is located at grain boundaries between calcite grains, contributing to the overall dark color of the ultramylonites. The regular $S$ and $C$ foliations that characterized some of the previous mylonitic stages are no longer present.

In Fig. 4, the microstructures associated with increasing mylonitization are shown schematically. Bent twins in calcite and core and mantle structures characterize the protomylonite (Fig. 4b). Calcite grains in the mylonitic stage (Figs. $4 c \&$ d) are equant in the relatively coarsegrained texture and elongate in fine-grained mylonite; the latter commonly displays $S-C$ structures. In the ultramylonitic stage (Fig. 4e), regular foliations ( $S$ and/ or $C$ ) are absent and irregular flow banding and very fine, equant grains of calcite are the primary optical characteristics.

\section{THERMOMETRY}

The significance of deformation microstructures is greatly enhanced by knowledge of the temperature at which they were formed (e.g. Hobbs 1985). Several reliable geothermometers are available for mylonites in metapelites that contain various combinations of garnet, aluminosilicate, phyllosilicate, quartz and feldspar (e.g. Essene 1989). Temperature determinations in relatively pure carbonates ( $>95 \%$ carbonate) in the greenschist and amphibolite facies, on the other hand, are mainly 


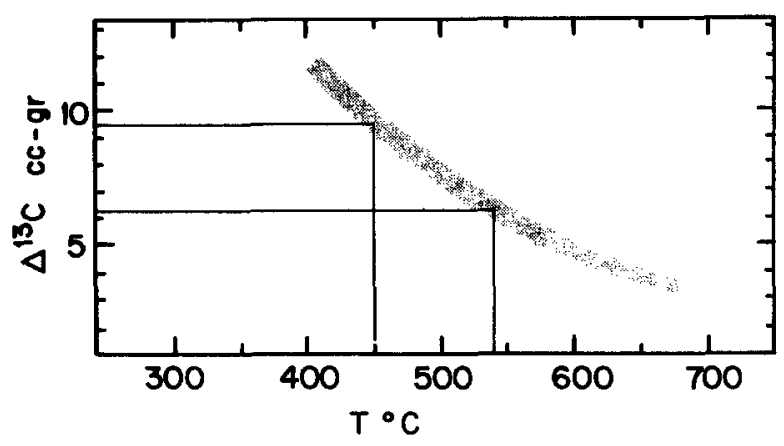

Fig. 5. The $\Delta^{13} \mathrm{C}$ isotopic fractionation of calcite-graphite pairs in fine-grained mylonite and ultramylonite (grain-size $<100 \mu \mathrm{m}$ ). The range of $\Delta^{13} \mathrm{C}$ values (6.2-9.5, Table 1) and associated temperatures $\left(450-540^{\circ} \mathrm{C}\right)$ are indicated with thin lines; the relationship between $\Delta^{13} \mathrm{C}$ and temperature is shown by the shaded band, which is based on Wada \& Suzuki (1983) and Morikiyo (1984).

restricted to calcite-dolomite (e.g. Anovitz \& Essene 1987) and calcite-graphite thermometry (Valley \& O'Neil 1981, Valley 1986). The calcite-dolomite geothermometer uses the $\mathrm{MgCO}_{3}$ content of calcite in equilibrium with dolomite to determine the metamorphic temperature. With decreasing grain size, however, it becomes more difficult to accurately obtain the chemical composition. Microprobe data on coarse-grained samples of the Bancroft shear zone were obtained for protoliths and protomylonites. Calculated temperatures from these analyses are greater than $600^{\circ} \mathrm{C}$ and agree well with earlier determinations by Sobol (1973, as reported in Essene 1983) in the same area. The temperatures from these large grains, however, reflect the metamorphic conditions during the earlier metamorphic history of these rocks and not those during mylonitization (van der Pluijm \& Carlson 1989).

Calcite-graphite thermometry is a method that uses the temperature dependent fractionation of ${ }^{13} \mathrm{C}$ between calcite and graphite (Valley \& O'Neil 1981, Wada \& Suzuki 1983, Morikiyo 1984). The analytical method for this application was presented in van der Pluijm \& Carlson (1989). It was found that exchange between calcite and graphite at relatively low temperatures is strongly dependent on grain-size, and approaches equilibrium conditions with decreasing grain-size (Wada 1988, van der Pluijm \& Carlson 1989). Thus, calcitegraphite thermometry is useful for samples with small grain-sizes $(<50 \mu \mathrm{m})$ and nicely complements calcitedolomite thermometry. Figure 5 combines five new analyses from mylonitic $(50-100 \mu \mathrm{m})$ to ultramylonitic $(<50 \mu \mathrm{m})$ samples with four earlier results from finegrained samples listed in van der Pluijm \& Carlson (1989). The $\Delta^{13} \mathrm{C}$ values in these fine-grained samples range from 6.2 to 9.5 (Table 1). Comparison of these values with the empirically derived relationship between temperature and $\Delta^{13} \mathrm{C}$ (Valley 1986) gives a temperature range of $450-540^{\circ} \mathrm{C}$ (Fig. 5). Considering that equilibrium conditions at these relatively low temperatures are only approached at the finest grain-size, it is concluded that a temperature of $475 \pm 50^{\circ} \mathrm{C}$ was reached during mylonitization. This temperature estimate is supported by the absence of annealing textures (cf. Griggs $\mathrm{et} \mathrm{al}$. 1960).
Table 1. Mean $\mathrm{C}$ and $\mathrm{O}$ isotopic data for calcite (cc) and graphite (gr) in fine-grained mylonites (grain-size $<100 \mu \mathrm{m}$ )

\begin{tabular}{lrrrrc}
\hline Sample & $\delta^{18} \mathrm{O}_{c c}$ & $\delta^{13} \mathrm{C}_{\mathrm{cc}}$ & $\delta^{13} \mathrm{C}_{\mathrm{gr}}$ & $\Delta^{13} \mathrm{C}_{\mathrm{cc}-\mathrm{gr}}$ & $\begin{array}{c}\text { Grain-size } \\
(\mu \mathrm{m})\end{array}$ \\
\hline BA-0 $\dagger$ & 18.6 & -1.1 & -10.6 & 9.5 & $<50$ \\
BA-3D $\dagger$ & 23.0 & 1.2 & -7.1 & 8.3 & $<50$ \\
BA-6B $\dagger$ & 26.6 & 0.4 & -7.5 & 7.9 & $<50$ \\
BA-28 & 21.6 & -2.0 & -9.6 & 7.6 & $<50$ \\
BA-31B & 21.7 & -1.8 & -8.2 & 6.4 & $50-100$ \\
BA-32 & 19.4 & -1.6 & -8.2 & 6.6 & $<50$ \\
GO-2A $\dagger$ & 22.7 & 1.8 & -5.6 & 7.4 & $<50$ \\
GO-12 & 15.8 & -2.3 & -8.5 & 6.2 & $50-100$ \\
GO-14 & 25.5 & 1.6 & -4.7 & 6.3 & $50-100$ \\
\hline
\end{tabular}

${ }^{*}{ }^{13} \mathrm{C}$ in ppm PDB (Peedee belemnite); ${ }^{18} \mathrm{O}$ in ppm SMOW (standard mean ocean water).

$\dagger$ Data from van der Pluijm \& Carlson (1989).

\section{DISCUSSION}

Calcite-graphite thermometry indicates that mylonitization of the Bancroft shear zone occurred at conditions near the greenschist-amphibolite facies boundary. Using a representative range for the geothermal gradient of $20-25^{\circ} \mathrm{km}^{-1}$ (Cosca et al. in press) and a temperature of $475^{\circ} \mathrm{C}$, the part of the shear zone currently outcropping was formed at a depth of about $20 \mathrm{~km}$.

Microstructures in samples from the Bancroft shear zone are remarkably similar to those observed in experimentally deformed carbonates and in natural quartzofeldspathic mylonites. By analogy, the microstructures of the marble mylonites are used to determine the active deformation mechanisms (cf. White et al. 1980, Groshong 1988, Knipe 1989). Furthermore, the empiricallyderived relationships between differential stress and microstructure, and the concept of deformation mechanism maps, provide a stimulating background for the discussion of these marble mylonites.

\section{Deformation mechanisms}

The two main mineral constituents of the mylonites are calcite and graphite and they display distinct microstructures. The behavior of each mineral is contrasted during the various stages of mylonitization in Fig. 6 . Equant, slightly serrated calcite grains in the protolith are generally twinned (Fig. 6a). Preliminary analysis of calcite twins following the methods of Turner (1953) and Spang (1972) located the compression axis $\left(\sigma_{1}\right)$ at an intermediate angle to the regional mylonitic foliation in an orientation that is in agreement with the inferred sense of shear (to the SW). This relationship is consistent with twinning as the deformation regime operative at low finite strains and compares well with Schmid et al. (1987), who reported similar results from twinning analysis on Carrara marble in simple shear experiments.

The occurrence of slightly deformed host grains, and subgrains and recrystallized grains near their edges (core and mantle or mortar structure) in the protomylonite (Figs. $6 \mathrm{~b} \& \mathrm{c}$ ), suggests that dislocation creep is the dominant deformation process (e.g. Barber 1985). 


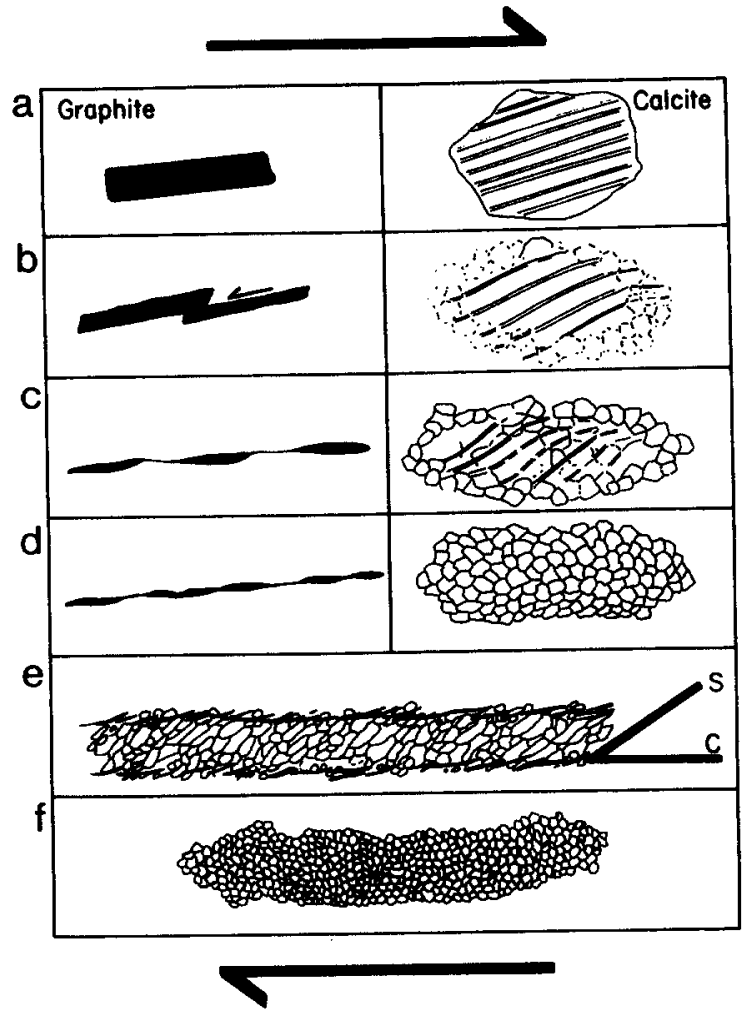

Fig. 6. Sketch of characteristic microstructures of calcite and graphite. (a) Protolith: large graphite flakes and twinned calcite grains. (b) Protomylonite; calcite subgrains and bent twins. (c) Protomylonite; core and mantle structure in calcite. (d) Coarse mylonite. (e) Fine mylonite; $S-C$ structure. (f) Ultramylonite. See text for detailed explanation.

Furthermore, the pattern across large grains from mildly deformed centers, to subgrains with bent twins, to recrystallized grains with straight grain boundaries (foam texture) near the edges, suggests that recrystallization occurred primarily by subgrain rotation (Poirier 1985, Urai et al. 1986, Knipe 1989). It is at this stage that the first dimensional-preferred orientation (DPO) formed, defined by elongate large calcite grains. This DPO was produced by dynamic recrystallization concentrated at grain boundaries and defines the mylonitic foliation.

Coarse mylonites have equant grains with a uniform grain-size and a well-developed foam texture (Fig. 6d). The size of these grains corresponds to that of the finegrained population at the rims of large grains in the protomylonite, which indicates that rotation recrystallization continued to transform large, protomylonitic grains into smaller recrystallized grains during this stage. Simultaneously, large graphite flakes were aligned into stringers of finer graphite flakes by a mechanism of basal plane slip (Figs. 6b-d). Such a mechanism would be analogous to the deformation of phyllosilicates in quartzo-feldspathic mylonites (e.g. Lister \& Snoke 1984).

Grain-size was further reduced in the fine mylonites, which are also characterized by grain elongation $(S-C$ structures, Fig. 6e). The reduced grain-size indicates that grain elongation does not simply result from flattening of originally equant grains, but that it involves grain
Table. 2. Experimentally-derived constitutive equations for (a) Solnhofen limestone and (b) Carrara marble, used in this study

$\begin{array}{cc}\text { Regime I (exponential law) } & \\ \dot{e}=10^{-0.12} \exp (-47000 / R T+\sigma / 160) & \text { (a) Rutter } 1974 \\ \dot{e}=10^{5.8} \exp (-62000 / R T+\sigma / 114) & \text { (b) Rutter } 1974\end{array}$

$\dot{e}=10^{5.8} \exp (-62000 / R T+\sigma / 114) \quad$ (b) Rutter 1974

Regime II (power law)

$\dot{e}=10^{-1.33} \exp (-71000 / R T) \sigma^{4.7} \quad$ (a) Schmid et al. 1977

$\begin{array}{ll}\dot{e}=10^{-5.5} \exp (-75000 / R T) \sigma^{6.0} & \text { (b1) Schmid } 1982\end{array}$

$\dot{e}=10^{3.8} \exp (-86000 / R T) \sigma^{2.9} \quad$ (b2) Schmid 1982

Regime III (superplasticity; compensated for grain-size)

$\dot{e}=10^{5.0} d^{-3} \exp (-51000 / R T) \sigma^{1.7} \quad$ (a) Schmid et al. 1977

Stress vs recrystallized grain-size

$\sigma=10^{3.67} d^{-1.01} \quad$ Schmid et al. 1980

$\dot{e}=$ strain rate $\left(\mathrm{s}^{-1}\right)$

$\sigma=$ differential stress (bar).

$T=$ absolute temperature $(\mathrm{K})$

$R=$ gas constant $\left(1.98 \mathrm{cal} \mathrm{mol}^{-1} \mathrm{~K}^{-1}\right)$.

$d=$ grain-size $(\mu \mathrm{m})$.

boundary migration (see also Lister \& Snoke 1984, Knipe \& Law 1987). Graphite stringers define a strong foliation in fine mylonites. It is noted that the presence of well-developed $C$-surfaces in protomylonite and coarse mylonite suggests that the $S$-surface in $S-C$ structures formed after the $C$-surface.

The absence of regular foliation surfaces, overall fine grain-size and commonly euhedral grains in ultramylonites (Fig. 6e) may indicate that finite strain accumulated by grain boundary sliding superplasticity (e.g. Poirier 1985). Experiments on Solnhofen limestone by Schmid et al. (1977) suggested the occurrence of this deformation mechanism in carbonates at small grain sizes. A remarkable similarity exists between their experimental microstructures (Schmid et al. 1977, fig. 6) and the natural textures observed in this study (Fig. 3c). The main difference between these experiments and the natural samples described is the larger grain-size of the natural samples. However, the lower strain rate at: natural conditions may allow superplasticity to occur at larger grain-sizes (Schmid et al. 1977).

\section{Differential stress and recrystallized grain-size}

Recrystallized grain-size may be used as an indicator of differential stress magnitude (e.g. Twiss 1977, White 1979, Hacker et al. 1990). Ord \& Christie (1984) and Twiss (1986) examined this relationship in detail and discussed examples for quartz and olivine. Poirier (1985) pointed out that grain-size is, at best, an empirical paleopiezometer that can only be used if the mechanism of recrystallization is well understood, i.e. rotation recrystallization or migration recrystallization, and that it may only indicate the maximum stresses.

Schmid et al. (1980) obtained a stress vs grain-size relationship from their experiments on Carrara marble (Table 2). The dominant recrystallization mechanism in the experiments was rotation recrystallization, which is considered the operative mechanism during the mylonitic stages of the Bancroft shear zone samples. In Fig. 7 the relationship of Schmid et al. (1980) is plotted against 


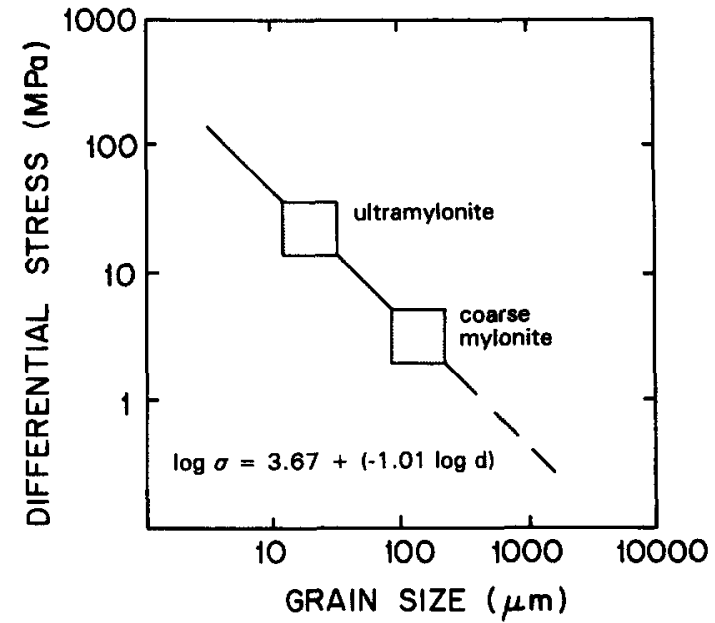

Fig. 7. Recrystallized grain-size $(\log d)$ vs differential stress $(\log \sigma)$. Based on the empirically-derived equation of Schmid et al. (1980, inset), the coarse mylonite and ultramylonite record differential stress magnitudes that range from $2-5$ and $14-38 \mathrm{MPa}$, respectively.

the recrystallized grain-size of coarse mylonite and ultramylonite in which stable microstructures are characterized by euhedral grains with straight grain boundaries. The protomylonite has a bimodal grain-size distribution, and the fine mylonite may reflect grain boundary migration; these samples were therefore not used. From the relationship in Fig. 7 we derive a differential stress range of 2-5 MPa for the coarse mylonite, and for the ultramylonite the range is $14-38 \mathrm{MPa}$.

\section{Deformation mechanism maps}

Ashby (1972) introduced the concept of deformation mechanism maps to the study of rock deformation. In deformation mechanism maps the conditions under which one deformation mechanism dominates is plotted in temperature vs stress space at constant grain size, or stress vs grain-size space at constant temperature for different strain rates (e.g. Langdon 1985, Poirier 1985). Deformation experiments on limestones and marbles (e.g. Rutter 1974, Schmid et al. 1980, 1987, Schmid 1982) at various conditions of stress, temperature, grainsize and strain rate, produced a number of flow laws that are representative for different deformation regimes. The temperature of mylonitization in the Bancroft shear zone was about $475^{\circ} \mathrm{C}$ and deformation mechanism maps were calculated for differential stress vs grain-size at constant $T$ using the equations listed in Table 2 . Two maps were constructed based on deformation experiments with very fine-grained $(4 \mu \mathrm{m})$ Solnhofen limestone (Fig. 8a) and a combination of Solnhofen limestone and medium-grained $(200 \mu \mathrm{m})$ Carrara marble (Fig. 8b).

At strain rates that are less than $10^{-10} \mathrm{~s}^{-1}$, samples with a grain-size greater than about $50 \mu \mathrm{m}$ are located in the field of power law creep (Regime II, Fig. 8). This prediction is in good agreement with the occurrence of subgrain formation and rotation recrystallization in the protomylonitic and coarse mylonitic stages. At similar strain rates, smaller grain-sizes generally fall in the field of superplastic behavior. Knipe (1989) discussed the importance of changes in local strain rate under conditions of bulk simple shear, and Schmid et al. (1977, 1980) observed work-softening in the superplastic regime where grain-size is small. This would suggest that an increase in strain rate accompanied the transition from mylonitic to ultramylonitic stage (Fig. 8). In fact, using the differential stress value of $26 \mathrm{MPa}$ and a temperature of $475^{\circ} \mathrm{C}$, a strain rate of $1.2 \times 10^{-10} \mathrm{~s}^{-1}$ is obtained with the equation for Regime III (Table 2).

Some complexity arises when the deformation mechanism maps of Fig. 8 are compared with the stress-grainsize relationship discussed in the previous section. The relationship shown in Fig. 7 would fall in the field of superplasticity (Regime III) for both deformation mechanism maps of Fig. 8. As was noted by Schmid (1982), one might expect this curve to lie in the field of Regime II if recrystallization by subgrain rotation was responsible for the microstructure. This inconsistency is removed if recrystallized grain-size results from a mechanism other than subgrain rotation (e.g. grain boundary migration), but this is not supported by the observations. Alternatively, heterogeneous deformation may have produced regions with reduced grain-size where superplastic behavior occurs, while rotation recrystallization continues to dominate the overall flow. Thus, the microstructure is initially controlled by one deformation mechanism, but as it evolves a different mechanism becomes increasingly important. Such coupling between the evolving microstructure and the dominant deformation mechanism cannot be adequately represented in a single deformation mechanism map because it assumes straininsensitive, steady-state flow.

\section{Displacement rates}

The various parameters obtained above can be combined to estimate displacement rates of the Bancroft shear zone. Information on the thickness of the active part of the shear zone (i.e. the effective thickness) is critical for this calculation. Field evidence indicates that the thickness of ultramylonite does not exceed $5 \mathrm{~m}$, which places an upper bound on displacement rates. The strain rate of $1.2 \times 10^{-10} \mathrm{~s}^{-1}$ corresponds to a shear strain rate of $2.4 \times 10^{-10} \mathrm{~s}^{-1}$ and gives a displacement parallel to the shear zone of $<38 \mathrm{~mm} \mathrm{yr}^{-1}$ (i.e. $<38 \mathrm{~km}$ per m.y.). Using a dip of $30^{\circ}$ for the Bancroft shear zone (Carlson et al. 1990), a relative vertical displacement rate of $<19 \mathrm{~mm} \mathrm{yr}^{-1}$ and a horizontal (extension) rate of

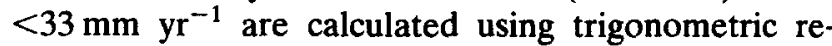
lationships. These values, however, require careful interpretation in view of the uncertainties associated with the various input parameters and the constitutive equations.

\section{CONCLUSIONS}

Mylonites of the Bancroft shear zone, which contain predominantly calcite and graphite, show a variety of 

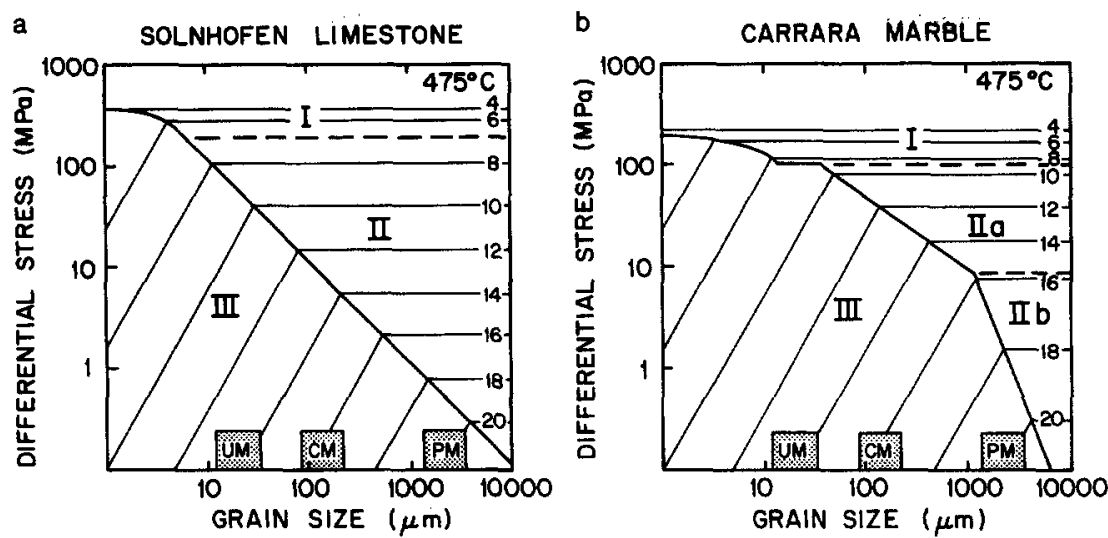

Fig. 8. Deformation mechanism maps for calcite at a constant temperature of $475^{\circ} \mathrm{C}$, based on flow laws for (a) Solnhofen limestone, and (b) a combination of Carrara marble (Regime I, Ila and IIb) and Solnhofen limestone (Regime III). Regime I is characterized by exponential creep (twinning); Regime II represents power-law creep (recrystallization); Regime III is dominated by grain boundary sliding superplasticity. Strain rates of $10^{-4}-10^{-20} \mathrm{~s}^{-1}$ are shown by their $-\log$ value. $P M=$ protomylonite. $\mathrm{CM}=$ coarse mylonite. $\mathrm{UM}=$ ultramylonite.

microstructures that were formed at medium metamorphic grade. Mylonitization is characterized by decreasing grain-size of both calcite and graphite. Grain-size in the protolith is on the order of several millimeters; in the mylonite stage it ranges from 50 to $200 \mu \mathrm{m}$; in ultramylonites the grain-size is $<30 \mu \mathrm{m}$. Calcite grain shapes are equant in the protolith, elongate in the protomylonite, equant in coarse mylonite, elongate in the fine mylonite and equant to slightly elongate in the ultramylonite. This grain-shape cyclicity suggests that external energy (applied stress), which tends to elongate grains, competes with energy sources internal to the grains (e.g. distortional strain) that favor equant shapes. Excellent correspondence exists between microstructures in experimentally deformed carbonates and these natural samples. Moreover, many features of quartzofeldspathic mylonites, such as core and mantle or mortar structures, mica fish, and $S-C$ structures, are present in these marble mylonites. $S-C$ structures are found only in samples of the fine mylonite (30-70 $\mu \mathrm{m}$ grain-size). The $C$-surfaces are marked by dark bands of graphite and very fine, elongate calcite grains (grain-size $<30 \mu \mathrm{m}$ ); the $S$-surface is defined by slightly larger, elongate calcite grains. Calcite grain-size reduction occurred predominantly by the process of rotation recrystallization. Graphite grain-size reduction occurred by separation along basal planes. $S-C$ structures developed after a mylonitic foliation $(C)$ was formed during the coarse mylonitic stage. Calcite grain elongation in the $S$ surfaces was accompanied by continued grain-size reduction and the activity of migration recrystallization, and is not a result of simple flattening of originally equant grains.

Calcite-graphite thermometry on the samples shows that the metamorphic conditions during mylonitization were $475 \pm 50^{\circ} \mathrm{C}$. The empirically-derived recrystallized grain-size vs differential stress relationship of Schmid $e t$ al. (1980) indicates that differential stresses were on the order of $26 \mathrm{MPa}$. Combined with the temperature determination, this differential stress gives a strain rate of $1.2 \times 10^{-10} \mathrm{~s}^{-1}$. Corresponding displacement rates were $<38 \mathrm{~mm} \mathrm{yr}^{-1}$.
This study shows that no single microstructure and, therefore, no single deformation mechanism is characteristic for a single temperature. Twinning (exponential creep; Regime I), recrystallization (power law creep; Regime II) and possibly grain boundary sliding superplasticity (Regime III) were all active during mylonitization. Changes in the dominant deformation mechanism were controlled largely by grain-size. This coupling between deformation mechanism and microstructure makes a deformation mechanism map that plots grainsize vs stress most useful. From such maps it is inferred that a significant strain rate increase characterized the ultramylonitic microstructure. The absence of steadystate flow (flow at constant stress and strain rate, Means 1981), however, somewhat limits quantitative analysis of the microstructures. For example the cyclic grain shape pattern prohibits the use of grain shape as a measure of finite strain (see also Means 1981, Lister \& Snoke 1984, Knipe \& Law 1987).

Acknowledgements-Research was supported by NSF grant EAR 89 03805. Kate Carlson, Eric Essene and Bernie Housen are thanked for discussions and comments. Reviews by two anonymous referees and Carol Simpson improved and clarified aspects of the paper. Calcitedolomite thermometry was carried out in the Electron Microbeam Analysis Laboratory and $\delta^{13} \mathrm{C}$ analyses were obtained by David Dettman in the Stable Isotope Laboratory, both at the University of Michigan. Susie Fast drafted the illustrations.

\section{REFERENCES}

Anovitz, L. M. \& Essene, E. J. 1987. Phase equilibria in the system $\mathrm{CaCO}_{3}-\mathrm{MgCO}_{3}-\mathrm{FeCO}_{3}$. J. Petrol. 28, 389-414.

Ashby, M. F. 1972. A first report on deformation mechanism maps. Acta metall. 20, 887-897.

Barber, D. J. 1985. Dislocations and microstructures. In: Preferred Orientation in Deformed Metals and Rocks: An Introduction to Modern Texture Analysis (edited by Wenk, H.-R.). Orlando, Academic Press, 149-182.

Barber, D. J. \& Wenk, H.-R. 1979. On geological aspects of calcite microstructure. Tectonophysics 54, 45-60.

Berthé, D., Choukroune, P. \& Jegouzo, P. 1979. Orthogneiss, mylonite and non-coaxial deformation of granites: the example of the south Armorican shear zone. J. Struct. Geol. 1, 31-42. 
Borradaile, G. J. \& McArthur, J. 1990. Experimental calcite fabrics in a synthetic weaker aggregate by coaxial and non-coaxial deformation. J. Struct. Geol. 12, 351-363.

Carlson, K. A., van der Pluijm, B. A. \& Hanmer, S. 1990. Marble mylonites of the Bancroft shear zone: Evidence for extension in the Canadian Grenville. Bull. geol. Soc. Am. 102, 174-181.

Cosca, M. A. 1989. Cooling and inferred uplift/erosion history of the Grenville orogen, Ontario: constraints from ${ }^{40} \mathrm{Ar} /{ }^{39} \mathrm{Ar}$ thermochronology. Unpublished Ph.D. thesis, University of Michigan.

Cosca, M. A., Sutter, J. F. \& Essene, E. J. In press. Late metamorphic cooling and inferred uplift/erosion history of the Ontario Grenville province: constraints from ${ }^{40} \mathrm{Ar} /{ }^{39} \mathrm{Ar}$ thermochronology. Tectonics.

Davidson, A. 1986. New interpretations in the southwestern Grenville Province. In: The Grenville Province (edited by Moore, J. M. Davidson, A. \& Baer, A. J.). Spec. Pap. geol. Ass. Can. 31, 61-74.

de Bresser, J. H. P. 1991. Intracrystalline deformation of calcite Geologica ultraiect. 79, 1-191.

Dietrich, D. \& Song, H. 1984. Calcite fabrics in a natural shear environment, the Helvetic nappes of western Switzerland. J. Struct. Geol. 6, 19-32.

England, P. C. \& Thompson, A. B. 1984. Pressure-temperature-time paths of regional metamorphism. I. Heat transfer during the evolution of regions of thickened continental crust. J. Petrol. 25, 894928.

Essene, E. J. 1983. Solid solutions and solvi among metamorphic carbonates with applications to geologic thermobarometry. In: Carbonates: Mineralogy and Chemistry (edited by Reeder, R. J.) Rev. Mineral. 11, 77-96.

Essene, E. J. 1989. The current status of thermobarometry in metamorphic rocks. In: Evolution of Metamorphic Belts (edited by Daly, J. S., Cliff, R. A. \& Yardley, B. W. D.). Spec. Publs, geol. Soc. Lond. 43, 1-44.

Friedman, M. \& Higgs, N. G. 1981. Calcite fabrics in experimental shear zones. In: Mechanical Behaviour of Crustal Rocks-The Handin Volume (edited by Carter, N. L., Friedman, M., Logan, J. M. \& Stearns, D. W.). Am. Geophys. Un. Geophys. Monogr. 24, $11-27$

Griggs, D. T., Paterson, M. S., Heard, H. C. \& Turner, F. J. 1960. Annealing recrystallization in calcite crystals and aggregates. $\mathrm{Mem}$. geol. Soc. Am. 79, 21-37.

Groshong, R. H., Jr. 1988. Low-temperature deformation mechanisms and their interpretation. Bull. geol. Soc. Am. 100, 13291360

Groshong, R. H., Jr., Teufel, L. W. \& Gasteiger, C. 1984. Precision and accuracy of the calcite strain-gauge technique. Bull. geol. Soc. Am. 95, 357-363.

Hacker, B. R., Yin, A. \& Christie, J. M. 1990. Differential stress, strain rate, and temperature of mylonitization in the Ruby Mountains, Nevada: implications for the rate and duration of uplift. $J$. Geophy. Res. 95, 8569-8580.

Hanmer, S. 1988. Ductile thrusting at mid-crustal level, southwestern Grenville Province. Can. J. Earth Sci. 25, 1049-1059.

Heard, H. C. \& Raleigh, C. B. 1972. Steady-state flow in marble at 500-800 ${ }^{\circ}$ C. Bull. geol. Soc. Am. 83, 935-956.

Heitzmann, P. 1987. Calcite mylonites in the central alpine 'root zone'. Tectonophysics 135, 207-215.

Hobbs, B. E. 1985. The geological significance of microfabric analysis. In: Preferred Orientation in Deformed Metals and Rocks: An Introduction to Modern Texture Analysis (edited by Wenk, H.-R.). Orlando, Academic Press, 463-484.

Knipe, R. J. 1989. Deformation mechanisms-recognition from natural tectonites. J. Struct. Geol. 11, 127-146.

Knipe, R. J. \& Law, R. D. 1987. The influence of crystallographic orientation and grain boundary migration on microstructural and textural evolution in an $S-C$ mylonite. Tectonophysics 135, 155169.

Langdon, T. G. 1985. Regimes of plastic deformation. In: Preferred Orientation in Deformed Metals and Rocks: An Introduction to Modern Texture Analysis (edited by Wenk, H.-R.). Orlando, Academic Press, 219-232.

Lister, G. S. \& Snoke, A. W. 1984. S-C mylonites. J. Struct. Geol. 6, 617-639.

Mawer, C. K. 1987. Shear criteria in the Grenville Province, Ontario, Canada. J. Struct. Geol. 9, 531-539.

Means, W. D. 1981. The concept of steady-state foliation. Tectonophysics 78, 179-199.

Morikiyo, T. 1984. Carbon isotopic study on coexisting calcite and graphite in the Ryoke metamorphic rocks, northern Kiso district, central Japan. Contr. Miner. Petrol. 87, 251-259.
Ord, A. \& Christie, J. M. 1984. Flow stresses from microstructures in mylonitic quartzites of the Moine thrust zone, Assynt area, Scotland. J. Struct. Geol. 6, 639-654.

Poirier, J.-P. 1985. Creep of Crystals. Cambridge, Cambridge University Press.

Rowe, K. J. \& Rutter, E. H. 1990. Palaeostress estimation using calcite twinning: experimental calibration and application in nature. J. Struct. Geol. 12, 1-17.

Rutter, E. H. 1974. The influence of temperature, strain rate and interstitial water in the experimental deformation of calcite rocks. Tectonophysics 22, 311-334.

Rutter, E. H. \& Rusbridge, M. 1977. The effect of non-coaxial strain paths on crystallographic preferred orientation development in the experimental deformation of a marble. Tectonophysics 39, 73-86.

Rutter, E. H. \& Schmid, S. M. 1975. An experimental study of unconfined flow of Solnhofen limestone. Bull. geol. Soc. Am. 86, 145-152.

Schmid, S. M. 1982. Laboratory experiments on rheology and deformation mechanisms in calcite and their application to studies in the field. Mitt. geol. Inst. ETH Univ. Zurich 241, 1-105.

Schmid, S. M., Boland, J. N. \& Paterson, M. S. 1977. Superplastic flow in finegrained limestone. Tectonophysics 43, 257-291.

Schmid, S. M., Casey, M. \& Starkey, J. 1981. The microfabric of calcite tectonites from the Helvetic nappes (Swiss Alps). In: Thrus and Nappe Tectonics (edited by McClay, K. R. \& Price, N. J.). Spec. Publs geol. Soc. Lond. 9, 151-158.

Schmid, S. M., Panozzo, R. \& Bauer, S. 1987. Simple shear experiments on calcite rocks: rheology and microfabric. J. Struct. Geol. 9 747-778.

Schmid, S. M., Paterson, M. S. \& Boland, J. N. 1980. High temperature flow and dynamic recrystallization in Carrara marble. Tectonophysics 65, 245-280.

Spang, J. H. 1972. Numerical method for dynamic analysis of calcite twin lamellae. Bull. geol. Soc. Am. 83, 467-472.

Spiers, C. J. 1979. Fabric development in calcite polycrystals deformed at $400^{\circ} \mathrm{C}$. Bull. Mineral. 102, 282-289.

Turner, F. J. 1953. Nature and dynamic interpretation of deformation in calcite of three marbles. Am. J. Sci. 251, 276-298.

Turner, F. J., Griggs, D. T. \& Heard, H. 1954. Experimental deformation of calcite crystals. Bull. geol. Soc. Am. 65, 883-934.

Twiss, R. J. 1977. Theory and applicability of a recrystallized grain size paleopiezometer. Pure \& Appl. Geophys. 115, 227-244.

Twiss, R. J. 1986. Variable sensitivity piezometric equations for dislocation density and subgrain diameter and their relevance to olivine and quartz. In: Mineral and Rock Deformation: Laboratory Studies-The Paterson Volume (edited by Hobbs, B. E. \& Heard, H.C.). Am. Geophys. Un. Geophys. Monogr. 36, 247-261

Urai, J. L., Means, W. D. \& Lister, G. S. 1986. Dynamic recrystallization of minerals. In: Mineral and Rock Deformation Laboratory Studies-The Paterson Volume (edited by Hobbs B. E. \& Heard, H. C.). Am. Geophys. Un. Geophys. Monogr. 36, 161-199

Valley, J. W. 1986. Stable isotope geochemistry of metamorphic rocks. In: Stable Isotopes in High Temperature Geological Processe (edited by Valley, J. W., Taylor, H. P., Jr \& O'Neil, J. R.). Miner. Soc. Am. Rev. Miner. 16, 445-490.

Valley, J. W. \& O'Neil, J. R. $1981 .{ }^{13} \mathrm{C} /{ }^{12} \mathrm{C}$ exchange between calcite and graphite: a possible thermometer in Grenville marbles. Geochim. cosmochim. Acta 45, 411-419.

van der Pluijm, B. A. \& Carlson, K. A. 1989. Extension in the Central Metasedimentary Belt of the Ontario Grenville: timing and tectonic significance. Geology 17, 161-164.

Wada, H. 1988. Microscale isotopic zoning in calcite and graphite crystals in marble. Nature 331, 61-63.

Wada, H. \& Suzuki, K. 1983. Carbon isotopic thermometry calibrated by dolomite-calcite solvus temperatures. Geochim. cosmochim. Acta 47, 697-706.

Wenk, H.-R. 1985. Carbonates. In: Preferred Orientation in Deformed Metals and Rocks: An Introduction to Modern Texture Analysis (edited by Wenk, H.-R.). Orlando, Academic Press, 361384.

Wenk, H.R., Kern, H., Van Houtte, P. \& Wagner, F. 1986. Heterogeneous strain in axial deformation of limestone, textural evidence. In: Mineral and Rock Deformation: Laboratory Studies-The Paterson Volume (edited by Hobbs, B. E. \& Heard, H. C.). Am. Geophys. Un. Geophys. Monogr. 36, 287-295.

Wenk, H.-R., Takeshita, T., Bechler, E., Erskine, B. G. \& Matthies, S. 1987. Pure shear and simple shear calcite textures: comparison of experimental, theoretical and natural data. J. Struct. Geol. 9, 731745 . 
White, S. 1976. The effects of strain on the microstructures, fabrics, and deformation mechanisms in quartzites. Phil. Trans. R. Soc. Lond. A283, 69-86.

White, S. 1979. Grain and sub-grain size variations across a mylonite zone. Contr. Miner. Petrol. 70, 193-202.

White, S., Burrows, S. E., Carraras, J., Shaw, N. D. \& Humphreys,
F. J. 1980. On mylonites in ductile shear zones. J. Struct. Geol. 2 , 175-187.

Wynne-Edwards, H. R. 1972. The Grenville Province. In: Variation in Tectonic Styles in Canada (edited by Price, R. A. \& Douglas, R. J. W.). Spec. Pap. Geol. Ass. Can. 11, 263-334. 